\title{
Exploring OECD SDGs pilot city's 50-year time series data and its Environmental Kuznets Curves
}

\author{
Quan-Hoang Vuong \\ Centre for Interdisciplinary Social Research, Phenikaa University \\ Yen Nghia, Ha Dong district, Hanoi 100803, Vietnam \\ hoang.vuongquan@phenikaa-uni.edu.vn \\ Manh-Tung Ho \\ Centre for Interdisciplinary Social Research, Phenikaa University \\ Yen Nghia, Ha Dong district, Hanoi 100803, Vietnam \\ tung.homanh@phenikaa-uni.edu.vn
}

Minh-Hoang Nguyen

Ritsumeikan Asia Pacific University, Beppu, Oita Prefecture, 874-8577, Japan

nmhhg8@gmail.com

\section{Working Paper No. PKU-1907}

Beppu, June 30, 2019

\begin{abstract}
Can green growth policies help protect the environment while keeping the industry growing and infrastructure expanding? This study applies Auto-Regressive Distributed Lag (ARDL) method on the 50-years' time series data, from 1967 to 2015, of Kitakyushu City, Japan, and found mixed evidence for Environmental Kuznets Curve (EKC) hypothesis. The analyses of NO2, Ox, falling dust particle, and SOx highlight a trilemma among the growth of industrial firms, infrastructure development, and reducing air-quality degradation. Nevertheless, for CO emission per capita, its logarithm has a general declining trend when plotted against both average firm size growth and paved road area expansion. This finding sheds light on the possibility of developing a regulatory framework that can harmonize a low-carbon society with industrial and infrastructure development.
\end{abstract}




\section{Exploring OECD SDGs pilot city's 50-year time series data and its Environmental Kuznets Curves}

\section{Quan-Hoang Vuong, Manh-Tung Ho, Minh-Hoang Nguyen}

Until now, Earth is the only known planet that shelters life, and, this life is under threat (1). Nonetheless, many who are in power are not willing to act to protect it. In a recent discovery, the Trump Administration tried to block a State Department senior intelligence analyst to give testimony on climate change (2). However, on the other side of the globe, the City of Kitakyushu, Japan, with governmental support, has been pursuing environmentfriendly industrial policies since 1967 (3) and in 2011, it was selected by OECD to be among four Green Growth Cities in the world besides Paris, Stockholm, and Chicago (4). This report presents striking results that could help evaluate the long-term impacts of the green growth policies on the relationship between air pollution and economic indicators such as average firm size growth and paved road area increase.

The research is possible thanks to the City of Kitakyushu's release of the 50-years time series data, from 1967, when the city first signed a pollution prevention agreement with the private sectors (5), to 2015 (6). The dataset includes industrial firm size (measured by shipment value), paved road area, and five air pollutants, namely falling dust particle (dust), Nitrogen dioxide $\left(\mathrm{NO}_{2}\right)$, Photochemical Oxidant $\left(\mathrm{O}_{\mathrm{x}}\right)$, Carbon Monoxide (CO), and Sulfur Oxides ( $\mathrm{SO}_{\mathrm{x}}$ ). We then perform the Auto-Regressive Distributed Lag (ARDL) method (7-9) on this dataset using the Environmental Kuznets Curve (EKC) model between the economic development indicators and air pollution $(10,11)$.

We find two separate patterns when plotting the growth of average firm size against various air pollutants since 1967: a general declining tendency for $\mathrm{NO}_{2}, \mathrm{O}_{\mathrm{x}}$ and $\mathrm{CO}$ emission per capita; and a $U$-shape curve when it comes to falling dust particle and $\mathrm{SO}_{\mathrm{x}}$ (see Figure 1). The logarithm of $\left(\beta_{1}=-0.5265, p\right.$-value $<0.05 ; \beta_{2}=0.0435, p$-value $<0.05$; and $\beta_{3}=-0.0012, p$ value $<0.05)$, PO $\left(\beta_{1}=-0.3772, p\right.$-value $<0.01 ; \beta_{2}=0.0299, p$-value $<0.01$; and $\beta_{3}=-0.0007, p$ value $<0.01)$ and $\mathrm{CO}$ emission per capita $\left(\beta_{1}=-0.6520, p\right.$-value $=0.134 ; \beta_{2}=0.0620, p$ value $<0.1$; and $\beta_{3}=-0.0018, p$-value $<0.1$ ) has a general downward trend when plotted against the average size of industrial firm. These results provided evidence for the EKC hypothesis which postulates economic development, or more particularly industrial growth, would have a bell-shaped curve with pollution, in which, pollution would start to fall after an introduction of regulation $(10,11)$. By contrast, the logarithm of dust $\left(\beta_{1}=-0.2466, p\right.$ value $<0.01$; and $\beta_{2}=0.0110, p$-value $<0.01 ; \beta_{3}=-0.0195, p$-value $\left.<0.1\right)$ and SOx emission per capita $\left(\beta_{1}=-2.0946, p\right.$-value $<0.05 ; \beta_{2}=0.2506, p$-value $<0.05$; and $\beta_{3}=-0.0095, p$-value $\left.<0.1\right)$ formed a $U$-shape relationship with firm's size, which provide an evidence against the EKC hypothesis. 

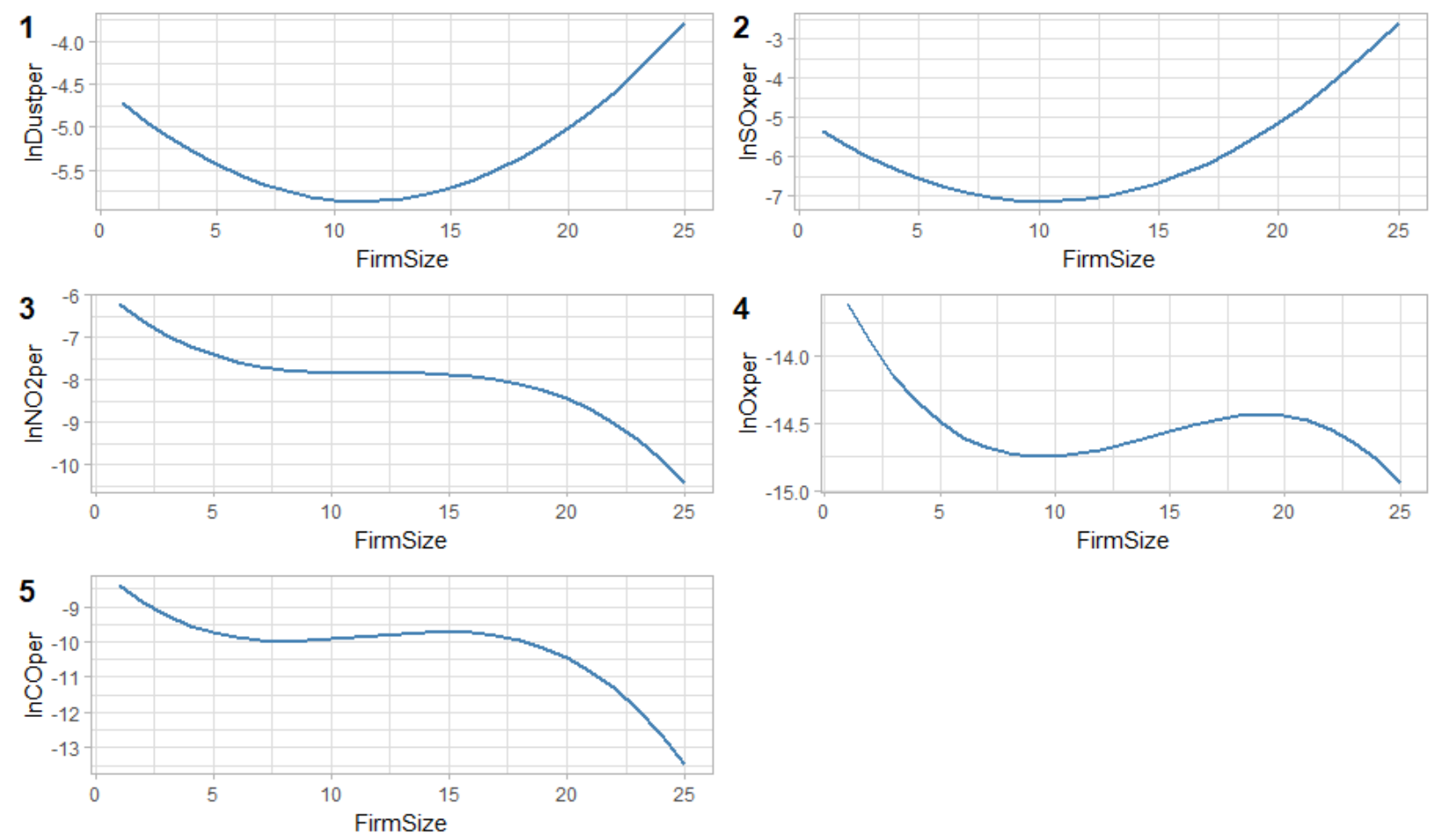

Figure 1: The trends of different air pollutants plotting against the growth of average firm size (million USD per firm).

The $U$-shape means as average firm size increases, the emission of dust and SOx starts to decrease initially, then pick up after average firm size reach around 12 million USD per firm. The diverging patterns in Figure 1 might be the results of the fact that the major sources of dust and $\mathrm{SO}_{\mathrm{x}}$ are industrial factories, while $\mathrm{NO}_{2}, \mathrm{O}_{\mathrm{x}}$, and $\mathrm{CO}$ come mostly from vehicles' burning of fossil fuels (12). Another explanation might be a shift in the industrial structure of Kitakyushu. In 2013, an OECD report on Kitakyushu's green growth expressed a worry that the existing regulatory framework had not kept up with the growth of small-medium enterprises (SMEs). The report noticed an increasing number of large corporations in iron steel, chemical, and automobile sectors, etc. , which are the main target of green growth regulation, started to outsource parts of their manufacturing process to SMEs, for which regulation is less stringent or more difficult to enforce (13).

As for the relationship between the air pollutants and the increase of paved road area in Kitakyushu, our study found the patterns are different. The logarithm of $\mathrm{NO}_{2}\left(\beta_{4}=0.0166\right.$, $p$-value $<0.05)$ and PO $\left(\beta_{4}=0.0102, p\right.$-value $\left.<0.05\right)$ concentration per capita increase as paved road area increase; while dust $\left(\beta_{4}=0.0195, p\right.$-value $\left.<0.1\right)$, SOx $\left(\beta_{4}=-0.0787, p\right.$-value $\left.<0.01\right)$ and CO $\left(\beta_{4}=-0.0136, p\right.$-value $\left.<0.1\right)$ emission per capita decrease as paved road area increase (Figure 2). The increased paved road area has induced traveling demand from households using personal vehicles, which resulted in an increase of $\mathrm{NO}_{2}$ and $\mathrm{PO}$ emission. OECD's report in 2013 has warned urban sprawl would have increased car dependency (13). On the other hand, the increased paved road area might result in better connections among industrial 
facilities, which enhance their productivity (14), hence leading to a decline in air pollutants such as dust and $\mathrm{SO}_{\mathrm{x}}$, as our results have shown.
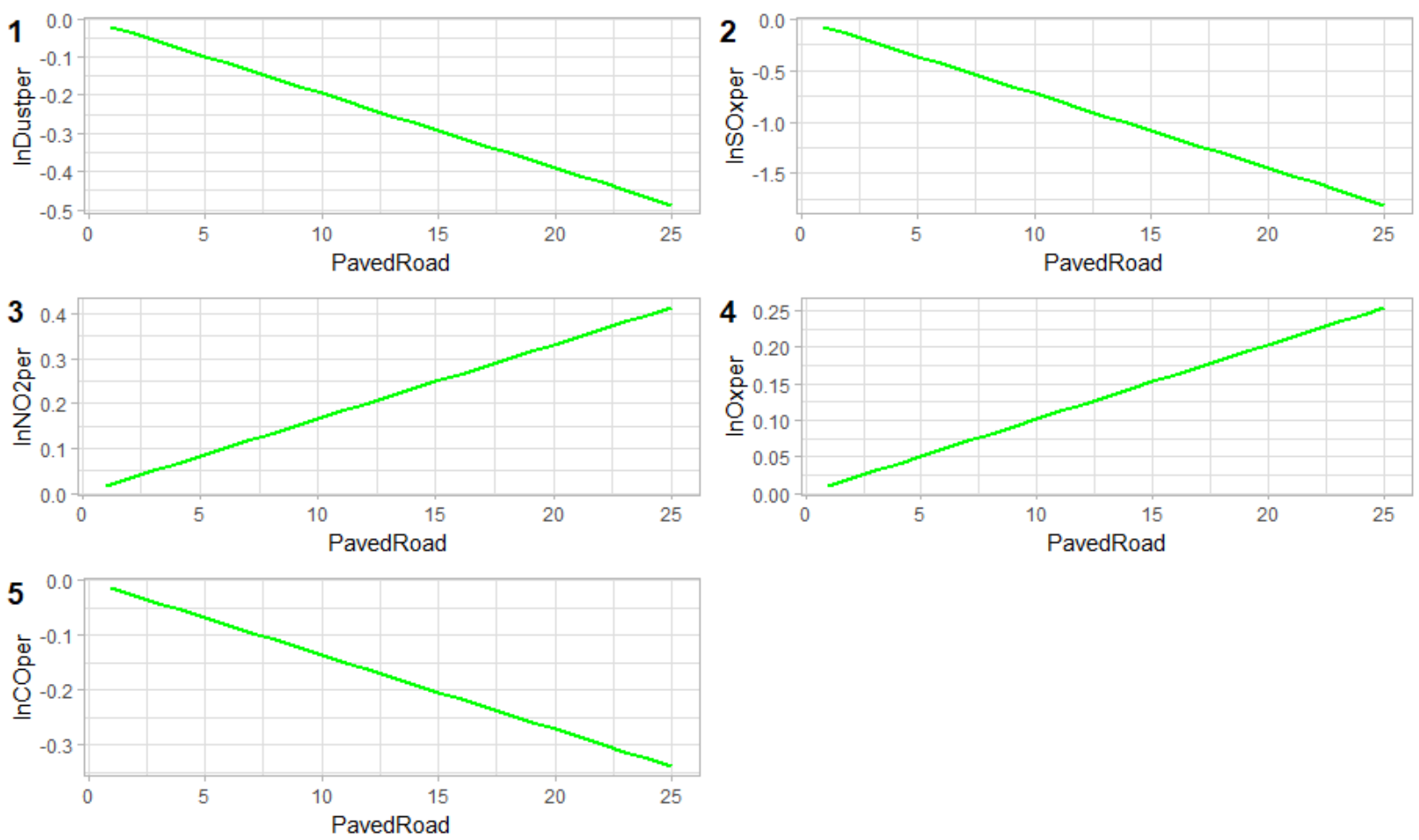

Figure 2: The trends of different air pollutants plotting against the increase of paved road area $(\mathrm{km} 2)$.

The declining trend of $\mathrm{CO}$ when plotting against both average firm's size and paved road area growth hints at the overall success or at least, some concrete achievements of the continued efforts of Kitakyushu to reduce carbon emission (3). This success has earned the city major national designations such as Eco-Town in 1997, Eco-Model-City in 2008, Smart Community Project in 2010, Future City Initiative in 2011, "Green Asia" Comprehensive Special Zone in 2011 (13), as well as, other international recognition (4). More importantly, it points to the possibility of a city able to manage seemingly contradictory tasks: keeping a lowcarbon emission yet developing industry and infrastructure. As such, it sheds light on the effectiveness of Kitakyushu to implement green growth policies, which could serve as a role model for not only other cities in Japan but also others in the world, especially, those in developing and OECD countries such as China, Korea or Vietnam (15).

Nonetheless, the optimistic result of controlling CO should not allow us to ignore the trilemma among the growth of industrial firms, infrastructure development, and reducing air-quality degradation, as shown in this study. Such mixed results highlight the enormous complexity and difficulty of pursuing green growth policies. Indeed, more and better science is needed (16) to advance our understanding of this long and treacherous path that humankind must take to avoid the disasters from environmental pollution and climate change. 
Author contributions: M.H.N. designed research; M.T.H. and M.H.N. performed research; Q.H.V. and M.H.N. analyzed data; Q.H.V. and M.T.H. wrote the paper.

\section{References}

1. Wallace-Wells D (2019) The uninhabitable earth: Life after warming (Tim Duggan Books, New York).

2. Friedman L (2019) White house tried to stop climate science testimony, documents show. in The New York Times. Available at https://www.nytimes.com/2019/06/08/climate/rod-schoonover-testimony.html (2019 June 14).

3. Low M (2013) Eco-cities in japan: Past and future. Journal of Urban Technology 20(1):7-22.

4. $\quad$ City of Kitakyushu (2018) Kitakyushu City the Sustainable Development Goals Report 2018. (Institute for Global Environmental Strategies, Kanagawa, Japan). Available at https://pub.iges.or.jp/pub/kitakyushu-city-sustainable-developmentgoals (2019 June 12).

5. Holroyd C (2018) Green Japan: Environmental technologies, innovation policy, and the pursuit of green growth (Japan and global society) (University of Toronto Press, Toronto).

6. City of Kitakyushu (長期時系列統計[Longitunal Statistics]. in Longitunal Statistics. Available at https://www.city.kitakyushu.lg.jp/shisei/menu05_0127.html (2019 June 13).

7. Ahmad N, et al. (2017) Modelling the CO 2 emissions and economic growth in Croatia: Is there any environmental Kuznets curve? Energy 123:164-172.

8. Ali W, Abdullah A, \& Azam M (2017) Re-visiting the environmental Kuznets curve hypothesis for Malaysia: Fresh evidence from ARDL bounds testing approach. Renewable and Sustainable Energy Reviews 77:990-1000.

9. Bölük G \& Mert M (2015) The renewable energy, growth and environmental Kuznets curve in Turkey: An ARDL approach. Renewable and Sustainable Energy Reviews 52:587-595.

10. Grossman GM \& Krueger AB (1995) Economic growth and the environment. The Quarterly Journal of Economics 110(2):353-377.

11. Özokcu S \& Özdemir Ö (2017) Economic growth, energy, and environmental Kuznets curve. Renewable and Sustainable Energy Reviews 72:639-647.

12. Thurston GD (2008) Outdoor Air Pollution: Sources, Atmospheric Transport, and Human Health Effects. International Encyclopedia of Public Health, ed Heggenhougen HK (Academic Press, Oxford), pp 700-712.

13. OECD (2013) Green growth in Kitakyushu, Japan. in OECD Green Growth Studies. Available at https://www.oecd-ilibrary.org/urban-rural-and-regionaldevelopment/green-growth-in-kitakyushu-japan_9789264195134-en (2019 June 11).

14. Duran-Fernandez R \& Santos G (2014) Regional convergence, road infrastructure, and industrial diversity in Mexico. Research in Transportation Economics 46:103110. 
15. Li Y \& Qiu L (2015) A comparative study on the quality of China's eco-city: Suzhou vs Kitakyushu. Habitat International 50:57-64.

16. Vuong Q-H (2018) The (ir)rational consideration of the cost of science in transition economies. Nat Hum Behav 2(1):5-5. 